\title{
Derrida and the Philosophy of Law and Justice
}

\author{
Simon Glendinning ${ }^{1}$
}

(C) The Author(s) 2016. This article is published with open access at Springerlink.com

\begin{abstract}
Readings of Derrida's work on law and justice have tended to stress the distinction between them. This stress is complicated by Derrida's own claim that it is not 'a true distinction'. In this essay I argue that ordinary experiences of the inadequacy of existing laws do indeed imply a claim about what would be more just, but that this claim only makes sense insofar as one can appeal to another more adequate law (whether the projection of a new law or an existing 'higher' law). Exploring how Derrida negotiates a subtle path between classical Platonism and classical conventionalism about justice, the attempt is made to take seriously Derrida's aim to affirm the idea of a 'mystical' foundation of the authority of laws by taking "the use of the word "mystical" in what I venture to call a rather Wittgensteinian direction'.
\end{abstract}

Keywords Conventionalism · Derrida $\cdot$ Justice $\cdot$ Law $\cdot$ Platonism · Wittgenstein

This essay explores how Derrida navigates between two main ways in which the relationship between law and justice has been understood in philosophy. That the relationship between law and justice is problematic and deserves attention can be introduced by way of a recent 'internet meme' that regularly gets tweeted:

Apartheid was 'legal'

Slavery was 'legal'

Simon Glendinning

s.glendinning@1se.ac.uk

1 European Institute, London School of Economics and Political Science, University of London, Houghton Street, London WC2A 2AE, UK 


\section{Colonialism was 'legal'}

Legality is a construct of the powerful, not of justice.

This more or less anonymous text, countersigned by thousands, attests to at least three and perhaps as many as six theses. First, that there is a history of laws. Second, that the history of laws relates a history of power. Third, that might is not right. Additionally, though these additions are unlikely to be immediately affirmed by its signatories, we might say, fourth, that law is constructed and can therefore be deconstructed. Fifth, that justice is undeconstructible. And, finally, sixth, that this work of deconstruction belongs to a movement of progress in the history of law.

This is perhaps a reasonable 'simple summary' of the kind of thinking that Derrida wants to affirm in his text 'Force of law: The "Mystical Foundation of Authority" (Derrida 1992). However, the subtitle to that text complicates that simplicity. The simple summary might suggest that the foundation of the authority of the law is external to justice: it is power, political power, a power which is arbitrary in the sense that what it constructs as law is simply in the service of its power. Derrida's subtitle will announce a complication to that (as I will call it) political conception. The complication is further complicated by the fact that while he will want to affirm something said in it, his subtitle quotes the words of someone else (and he includes the quotation marks in the subtitle), and in order to affirm it he will want to take it in, or read in it, a direction other than its intended one. Rather than simply the political foundation of authority, Derrida's subtitle speaks (in quotes) of the 'mystical foundation of authority'. And within the space he subsequently opens up for thinking the problematic relation between law and justice announced by the simple summary, Derrida will also affirm that 'it is just that there be law' (1992, p. 22).

Derrida became a significant presence in discussions of 'theory' during the late 1960s. However, with the publication of 'Force of Law: The "Mystical Foundation of Authority", in 1992 it became impossible not to register a special connection between what Derrida was calling 'deconstruction' and specifically legal theory. In that essay Derrida drew his own work into relation with themes right at the heart of legal thinking, and did so in a new and dramatic way: deconstruction, the work of reading the movement of the Western philosophical heritage (which was disclosed therein as never simply philosophical through and through), was not to be thought of merely as a procedure or practice or process that promised a more just theoretical end or some kind of judicious advance for critical thinking, but as the very movement of justice in its relation to law. 'Deconstruction', Derrida announced, 'is justice' (1992, p. 15).

There had been writings by Derrida on law-related themes before, and a number of legal scholars had attempted to apply lessons from deconstruction to lawyerly concerns, but the audacious identification of deconstruction with justice opened the door to something rather different. Not just the application of a motley of newlyminted terms of art (différance, trace, undecidability, iterability, arche-writing, dissemination, logocentrism, phonocentrism, and so on) to the old domain of legal philosophy but the potential transformation of that domain. Legal philosophy, one might think, could do much more than 'apply' or 'use' Derrida, or find his work 
'helpful' for already existing concerns or ambitions; it could retrace its steps and learn anew how to read its own heritage, formation and problematic field.

As I have tried to show elsewhere, this is not what happened (Glendinning 2011). On the contrary, many of those most keen to find Derrida 'helpful' to their cause in legal theory cut to the chase: the question is not the philosophical one about the foundations of legal authority and the possibility of justice, but the political one about the violence of existing legal authority and the current absence of justice.

The latter are themes for Derrida, without a doubt. Indeed, what, in 'Force of Law' he calls 'the experience of inadequation' of existing laws with respect to justice (1992, p. 20) is fundamental to his effort consistently to follow, as far as possible - though insisting as well that it is not 'a true distinction' (1992, p. 22) the kind of contrast between laws (droit) and justice that is in view in the simple summary. And Derrida is equally insistent that the aporias he attends to should in no way stop one in one's tracks (leaving one without a path, a-poros), and thus prevent one from getting actively involved in 'juridico-political battles' (1992, p. 28). On the contrary, what is required, he argues, is not to take 'emancipatory battles' beyond the law, but to take the law, or at least the element of calculation that he regards as essential to legal reasoning, into every field in which there is an appeal to justice. As we shall see, the idea of the calculability of law here relates to the generality of a rule, and of reasoning that in principle would apply to anyone. The corresponding 'incalculability' of justice that Derrida also insists upon relates to decisions which are themselves always singular, concerning individuals or collectivities that are radically irreplaceable in situations that resist generalisation. Law, Derrida argues, is nevertheless the best way, the most just way, we have for organising a response-a politicizing response not in the least excluded-to such singularities: 'incalculable justice requires us to calculate' (1992, p. 28), it provides the institutional apparatus par excellence through which we can engage in 'emancipatory battles that remain and will have to remain in progress' (1992, p. 28). Moreover, it enables us to do what we can not only in already identified 'territories of juridico-politicisation' (1992, p. 29) but also in new and presently underdiscussed areas. Derrida runs through an open list of examples, many of which would be familiar in what is today called 'applied philosophy': 'the area of laws on the teaching and practice of languages, the legitimisation of canons, the military use of scientific research, abortion, euthanasia, problems of organ transplant, extrauterine conception, bio-engineering, medical experimentation, the social treatment of AIDS, the macro- or micro-politics of drugs, the homeless, and so on, without forgetting, of course, the treatment of what we call animal life, animality' (1992, pp. 28-29). It is in view of a history of progress in the development of law in the past and hope for success in emancipatory battles like these that Derrida will insist, as I have indicated, that 'it is just that there be law' (1992, p. 22).

But what about the contrast I have just so rapidly introduced between philosophical questions and political questions? That, surely, is alien to Derrida, alien to the thought that discloses the Western philosophical heritage as never simply philosophical, but as, for example, fundamentally ethnocentric or Eurocentric. 
Indeed, it is precisely in view of that more-than-philosophical interest so clearly internal to Derrida's work that the kind of legal theory which seeks the privileging of what I am calling the political question, even the politicisation of every problem, embraced Derrida and 'Force of Law' in the first place. As I say, there is reason to find an 'ally' there, something to be welcomed by such theory (although, having said that, I have never seen any such theorists take any interest in Derrida's 'Force of Law' list of examples). On the other hand, and this would not be so welcome, Derrida is equally insistent that politicisation 'should not ever be total' (1992, p. 28). This resistance to limitless politicisation would be uncongenial for that strand of legal theory which seeks the immediate transformation of every question or problem into a matter of legal-political calculation. The idea that there should be a limit to the extension of the political and a limit to politicisation is, from that perspective, barely intelligible, and in any case politically suspicious. And yet, according to Derrida it is precisely that which exceeds the order of legal-political reason (in virtue of its non-generalisability and singularity) that provides the basic impetus to every legal-political intervention.

In line with the simple summary, and emphasising the distinction between law and justice, legal theory which concerns itself above all with the political question might nevertheless take Derrida's work to outline a political hope for what the author of an essay in an edited collection, Derrida and Legal Philosophy (Goodrich et al. 2008) has called 'justice outside of law' (2008, p. 197). On a generous reading this is nearly right since Derrida construes justice in 'Force of Law' as that which 'exceeds law and calculation' (1992, p. 28). However, to situate this as simply 'outside' of law is to get Derrida's emphasis on singularity almost exactly wrong and cannot but present him as someone ultimately hostile to legal reasoning and argument; as someone ultimately convinced that, at least up until now, law has been fundamentally an instrument of violence and arbitrary power. That kind of view can, of course, seem compelling: beyond the simple summary, we know how powerful nation states, for example, have come to dominate the application and interpretation of laws that are supposed to be international. However, unlike academic legal scholars who privilege the political question, Derrida does not take such imbalances in the relation between justice and power to justify taking a generally cynical view of law, or to regard appeals to legality as everywhere a camouflage for political selfinterest. The two examples of historic emancipatory battles that Derrida cites, the Declaration of the Rights of Man and (not the legality but) the abolition of slavery (1992, p. 28), are both, as he puts it, 'juridico-political battles', and the list of future causes already mentioned does not call for action 'outside' of law either, even if the causes are, today, beyond already established areas of 'advance in politicization', and hence call for transformations in the current field of 'juridico-politicization' (1992, p. 28).

The strand of legal theory I am contrasting with Derrida here is dominated by the well-established orthodoxy of 'critical legal studies'. And the complex relation, the disjunctive conjunction, between what Derrida called his kind of 'philosophicodeconstructive questioning' (1992, p. 9) and that well-established orthodoxy is one which Derrida draws brief but explicit attention to in 'Force of Law'. On the one hand, he sees in both an effort to avoid a conception of academia as the 'monastic 
ivory tower' 'enclosed in purely speculative, theoretical, academic discourses' (1992, p. 8). Like the critical legal orthodoxy, Derrida always insists on the need to 'change things...not only in the profession but...in the world' (1992, p. 9). On the other hand, however, Derrida also anticipated finding 'disparities and disputes' as well as 'agreements' between them (1992, p. 9), and he very boldly called the work in 'critical legal studies' that he was familiar with 'uneven, timid, approximating and schematic, not to mention belated' (1992, p. 9). Scholars engaged in such 'critical legal studies' (the inverted commas were also a constant in Derrida's discussion of the conjunction) must have been taken aback to be accused of being yesterday's men and women-having thought of themselves as precisely tomorrow's.

So perhaps something of the contrast between philosophical questioning and the political questioning of 'critical legal studies' can be sustained. Admitting at least something of that, what then is the focus of Derrida's 'philosophico-deconstructive' reflections on law and justice?

Derrida had contrasted what he wanted from his deconstructive questioning from '(with all due respect to Stanley Fish)' a purely theoretical discourse. Nevertheless, it takes its orientation from an effort to negotiate a new theoretical passage between the two great traditions which have dominated theoretical philosophy of law for centuries: Platonism (and its related idealist and intellectualist variations) and conventionalism (and its related empiricist and historicist variations). By Platonism I mean the theoretical stance claiming that a satisfactory response to the question 'what is justice?' requires rational, theoretical, insight into the idea of justice; ultimately a matter of grasping the ideal form of human social and individual life. By conventionalism I mean the theoretical stance claiming that legal institutions and laws have their 'foundation' in what are ultimately arbitrary and contingent conventions. The latter demands of anyone seeking to understand what is called 'justice' that he or she adjusts his or her attention and reasoning to something like the 'customary ways of going on in some historical time and place'; the former demands that he or she adjusts his or her reasoning to something like 'the truth of justice as such'. In contrast to both, the reader of Derrida's 'Force of Law' will find an emphasis on performativity (developing J.L. Austin's ground-breaking work on performative utterances), which challenges the privilege accorded to truth and theoretical cognition that one finds in classic Platonism, and equally, an emphasis on a certain unpresentable 'there is' of justice which challenges the reduction of justice to arbitrary rules and local customs that one finds in classic conventionalism. Derrida signals the route for his passage between these positions when he states that his central argument "takes the use of the word "mystical" [as found in conventionalist texts by Montaigne and Pascal] in what I'd venture to call a rather Wittgensteinian direction' (1992, p. 14). Derrida also hints at the possibility of bringing his discussion into relation with other important texts in contemporary legal philosophy: for example, with 'Stanley Fish's discussion in "Force" (Doing what Comes Naturally), of Hart's Concept of Law, and several others, implicitly including Rawls' (1992, p. 14). There is, then, considerable scope for further development, discussion and exploration of the ideas broached by Derrida in his work on the theme of deconstruction and the possibility of justice. 
As far as I can see, neither Platonism nor conventionalism, nor J.L. Austin and the analysis of performative utterances, nor Wittgenstein and the novel use of the word 'mystical', nor texts by Montaigne, Pascal, Fish, Hart, or Rawls, get much of a mention in the literature on Derrida's thinking on law and justice. Indeed, in the recent collection I referred to a moment ago, none of them get a single mention. None of them. Not one.

When Derrida's work became fashionable in 'theory', it was largely received as a novel and radical critique of the heritage of Western philosophy. I think that idea of it was enjoyed so much at least in part because it was regarded as enjoining the destruction of that heritage. But right from the start Derrida had insisted that 'deconstruction', as he understood that, was not destroying. It was not rejecting. Indeed, Derrida insisted that he 'loves the texts that [he] reads in a deconstructive manner' (1988, p. 87). What he wants is not, of course, to repeat the way those texts have tended to be read (even-perhaps especially - by themselves as it were), but to open them, and thus to open the heritage, to a future beyond that self-understanding, and to attest or bear witness to something of this movement already at work and underway within them. If deconstruction announces a kind of break or passage beyond the classic constructions of the philosophical heritage, this is not effected through a critique or intervention from outside it, but this openingresisted as it certainly is by the dominant structures of its formation-is disclosed within the very heritage itself. Deconstruction attests to the movement of a heritage breaking with itself beyond itself 'within' itself.

That 'beyond' he calls 'the future'. This is not the kind of future one might present in the present, in the way reading a preface, for example, presents something of the main text in advance. It is the future beyond every presently anticipated future, the future beyond 'the closure of knowledge' as he put it in Of Grammatology (1998, p. 4). Deconstruction as a loving work of reading the heritage has the form of wanting it to have such a future, and it is sustained only by a hope that its work will have been faithful to that future: a kind of preface to what remains to come. However, in this case the main text is, precisely, not given. Yet, through a sort of auto-poetic propulsion, it aims to make it so that it will have been or belonged to a path-forging movement towards a 'future world' beyond current anticipation, beyond knowledge or theoretical insight. And this 'future world' is not conceived of as some ideally just condition, of perpetual peace or final adequacy. On the contrary it would be a future world for which a future world beyond itself also remains to be thought. It is a constant battle against what J.S. Mill calls 'stationariness' (1978, p. 68).

Derrida also calls this endless movement an openness in every here and now to justice to come. And it is his thoughts specifically about justice that I am going to be exploring in this essay, and how these illuminate both legal reasoning and the limits of justification in legal judgement.

I want to begin by considering the idea of a law before it comes into force. Think, for example, of the law in the UK for wearing a seat-belt in a car. On the last day of January 1983 a law on seat-belt wearing came into force in the UK. Before that day, 
there had been no such law. No such legal obligation. No such: you must wear a seat-belt. We can distinguish two different kinds of 'day before that day'. Some time before that date, perhaps many years before that date, there had been little or no anticipation of that law. Seat-belt wearing was entirely voluntary. Indeed, most cars did not even have seat-belts. But even then, there were numerous laws surrounding the safe driving of a car and the proper maintenance of it and so on, and so even then there was perhaps a certain imminence on the horizon of a law to come, perhaps a growing restlessness within the authorities to consider legislating and making laws which could be in force (this really got started in 1973). Nonetheless, any law was a law to come, and had as yet no force.

Now a second moment: 30 January 1983, the day before the law comes into force. Now, we are all getting ready for the change in the law; what was at most voluntary is about to become obligatory for everyone. The law is also ready: it is written, it has been announced, but, by the force of another law, indeed from the moment that the Queen signed a Bill and made it a Statute, its force was delayed to a certain date to come; a date explicitly anticipated and inscribed within the Bill which became a Statute at the moment that the Queen signed it.

Let us ask about this sovereign signature event. Was there or is there a law or Statute which specifies that upon the appending of the Monarch's signature the Bill becomes a Statute? I think there probably is. But what gives that law its force? Is it another signature on another Bill? And if that law has force in virtue of some authorising signature (I am using this as a symbol that helps to compress the structure of relations we are dealing with here in terms of the authorising of the law), if, that is, the signature event has the force of law in virtue of another signature, then what about that signature? And so on.

The regress here should be clear. Whenever anything is appealed to as a law in force, we can always step back at each point and ask questions about the authority that brings the law into force, or gives the law force. So, and this is Derrida's question: what is the origin of the force of law?

In order to bring the regress to a halt one might distinguish between the force of law of an existing authority, and the coming to force of such a power. It would seem that the latter could not be authorised by any anterior legitimacy, and hence can only be in force from force itself.

With respect to this case, the coming to force of a ruling authority, whatever movement or power brings it into being must be a movement that is in itself, as Derrida puts it, 'neither legal nor illegal' (1992, p. 6). It is prior to any distinction between the legal and illegal because it is precisely what brings into force the institutions of legality and legal justification. However, Derrida does not see this structure as belonging only to the instituting case. Indeed, it highlights something that he will see applying not only to legal institutions, or sovereign powers, but also to moments of decision within such institutions; indeed precisely those momentslegal judgments and decisions - in which justice is, as we say, 'done'. At such points he is going to say there must be a force (in fact, as we shall see, a 'performative force') that acts in a certain way 'before the law'. Does this mean, as a crude reading of the simple summary might suggest, that the law is to be seen as 'in the last instance' an instrument at the service of an arbitrary power? The law 
certainly comes to be in history, and 'to be' for the law requires a force that has to be, in a certain way, before it. But Derrida resists an historicist reduction of this point, and will argue that the 'neither legal not illegal' force that founds the law is not simply external to it. The law will not be seen as the instrument of a force, whether economic, political or ideological, that would exist outside or before the instruments of legality.

The point is a logical one: the sense in which it is before the law is that no justificatory discourse could provide a metalanguage for it that is prior to its institution, or if we did have some justificatory discourse then we could just ask: and where does the force of that derive from? We would again move on our regress-or move in a circle. Derrida's response will be to deny both that justification comes to an end with a founding act that is self-justifying (or, say, intrinsically just), and to deny that the intrinsically 'violent structure of the founding act' makes the law simply an instrument of power.

Derrida's difficult claim here, the point that will distinguish his thought from an attractive interpretation of the simple summary, is that this moment of violence before the law, which founds the law, is not simply external to the law nor is it something that might be eliminated by an ideally just regime. I am going to try to give some accounting for this thought - a thought which holds off from the political temptation to reduce law to an instrument in the service of power.

\section{III}

At issue here, fundamentally, are events that are not logically or epistemologically compelled by the justifications that are offered for them. Derrida calls these events 'performative'. He takes that word from the British philosopher who was also a huge influence on H.L.A. Hart, J.L. Austin, and the analysis of the performative utterance developed in Austin's book How to Do Things with Words (Austin 1975). Austin's initial proposal in that text is to distinguish between two kinds of utterances or speech acts, which he calls 'constative' and 'performative' respectively (1975, p. 1). A constative speech act is one that aims at truth. Or, to put it another way, the kind of thing that can 'go wrong' with this sort of speech act is that someone saying it says something false. It is an act of 'saying how things are', or of making a claim about how things are, and its basic character is that its success conditions are its truth conditions.

A performative is an utterance, a speech act which cannot be assessed in terms of truth. Austin's first example is of somebody getting married, and their saying: 'I do'. When you say those words in a marriage ceremony you are not reporting on a wedding, you are indulging in one. It does not state something about a situation but changes it. In this case it brings it about that you are now married. Another (related) example he gives is promising. I promised the editors to write an essay on Derrida on law and justice. A promise does not report some fact that existed prior to me promising: in promising I bring it about that I have a certain commitment-which I may fail to live up to. 
Now, these performative acts also have what one might call success conditions. The constative utterance's conditions of success are truth conditions. The performative has conditions of success too, but these are generally speaking conventions. So, for example, if someone standing next to you in a cinema queue happens to say to you 'I do', they have not just got married to you. That is because all sorts of conventions are involved in making it so that when somebody speaks those words they have their conventional performative effects: to be legally wed you and your intended have to be in the right kind of place, and the ceremony has to be conducted by someone with the right kind of authority, and so on. Then and only then is the utterance 'I do' indulging in a marriage. So the performative does not have truth conditions but there are conventions related to its success. These conventions enable the speech act to have the force it does.

To get ahead of ourselves, the force that Derrida wants to talk about that is neither external to the law nor compelled by the justificatory discourse of legal reasoning is akin to an Austinian performative force. But Derrida notes that with the instituting of the conventions that the law as law depends on, we are not reaching a source or origin from which we can derive the force of law. Again, we would just be shifting the question one stage back, and would have to ask where these conventions derive their force as 'success conditions' for the force of law. Justification comes to an end-but not with something that, as it were, carries its force on its face. It is here that Derrida appeals to the idea of a " "mystical” limit' (1992, p. 14) that every discourse bumps up against in its effort to find the origin of the force of law.

This mystical limit will, he says, reappear at the supposed origin of the conventions of any performative. So at every stage where we seem to find something from which we can establish the source of the force of the law, Derrida will invite the question of its authority. At this point his argument shifts from Austin to another philosopher of language, to Wittgenstein. While he takes the word from a conventionalist text by Montaigne, Derrida says he will 'take the use of the word "mystical" in what I venture to call a rather Wittgensteinian direction' (1992, p. 14): a Wittgensteinian sense of the mystical limit.

This is already a novel turn. The critique of conventionalism in the philosophy of law has a standard opponent, and the standard opponent to the conventionalist is the Platonist. The Platonist argues that the force of law derives not from customs and conventions, but from a sense of what justice is that is radically independent of anything we historically elaborate in its name. Our conventions are the right ones if they accord with justice and justice would be thought here as something before the law which the appropriately adjusted mind would grasp: we grasp the form or the truth of justice, and we would do so in a theoretical cognition, something that might be expressed in a constative way. For the Platonist it will be the truth of justice that will underpin the force of law.

That is the standard opposition: between the conventionalist, for whom the force of law derives from contingent conventions, and the Platonist who says that it derives from the form of justice itself utterly independently of historically contingent conventions.

So the fact that Derrida engages critically with conventionalism brings his account into a relation to the standard alternative, with Platonism. And in fact his 
position has characteristics quite similar to Platonism. However, because he is going to affirm a certain performativity (irreducible to a kind of knowing) internal to the moment-of-judgement in which, as we say, justice is 'done', his account is also importantly different from a classic Platonist. There is a constellation of three positions on justification here. A Platonist sense of the limit is to say that justification comes to an end with a legal argument that is rationally compelling, which demands that it is guided and compelled by our grasp of what is just. The conventionalist says that when justification comes to an end we come to (ultimately arbitrary) conventions. Derrida invites a Platonist response to conventionalism by insisting against the conventionalist that when we hit the 'final convention' we can still ask where its force comes from. Against the Platonist, however, Derrida will insist that there is no justification-which will ultimately be, as the conventionalist says, an appeal to legal conventions - which closes off every question concerning what it requires of us. The limit we hit when we arrive at conventions is not something we can go back behind, and yet the fact that justification comes to an end with these conventions does not mean that they are the origin of the force of law. Justification comes to an end somewhere. However, it ends only with a convention, not with the demonstration of a truth. This is not a dogmatic limit authorised merely by an arbitrary authority—so that 'might makes right' — but what Derrida will call, following his 'Wittgensteinian' turn, a 'mystical' limit.

\section{IV}

When I first read 'Force of Law', I read it from a photocopy given to me by a colleague of his original. He had annotated it very heavily, and the text was covered in his writing. It is enjoyable reading somebody else's way of trying to come to terms with a text, tracking their tracks through its tracks. But at the point where Derrida speaks of the Wittgensteinian sense of the mystical limit, my colleague wrote something in the margins that especially intrigued me: '= early Witt?' This is a completely understandable hypothesis. That is because the only references to the mystical in the entire corpus of Wittgenstein's work are in his early work, his first book, the Tractatus Logico-Philosophicus (Wittgenstein 1961). In that text he famously states that 'it is not how things are in the world that is mystical, but that it exists' (1961, 6.44). He also says there are things that 'cannot be put into words, but which make themselves manifest', and that they are what is 'mystical' (1961, 6.522). At the limit of language, when the possibility of saying something with a sense gives way, there is only nonsense. (Not a nonsensical sense, but sheer senselessness.) However, as Wittgenstein put it at the end of a brief comment on Heidegger in conversation with the Vienna Circle, the inevitably misfiring attempts to say something about the world in its being-the upshot of wanting to 'go beyond the world and that is to say beyond significant language' (Wittgenstein 1993, p. 44) may nevertheless be regarded as a sort of gesture, a movement of mind that 'points to something' (Murray 1978, p. 80). Wittgenstein had called this running up against the limits of language 'ethics': we think we have our eyes open to the Good, just as 
we might have our eyes opened to something that is the case, incarceration rates in America, for example.

Unproblematically, an 'experience of inadequation' of American penal laws (and their application) implies a claim about what would be more just, and hence makes sense only insofar as one can appeal to another more adequate law (whether the projection of a new law or an existing 'higher' law). But now, just as (we might reasonably say) this sense of justice illuminates the shortcoming of the law, so we might imagine undertaking an attempt to articulate our sense of justice itself: to open our eyes to what is just überhaupt. The Wittgensteinian sense of the mystical limit urges us to come to terms with the fact that there is no such coming to terms with 'justice as such'. The law or laws through which we (intelligibly) express our sense of the inadequation of existing laws speaks of something about which we cannot intelligibly speak: namely, that there is justice, or to put it better, about the 'there is' of justice. This is what we might call an acknowledgment of the mystical limit, and I think it is fundamental to Derrida's argument in the philosophy of law and justice.

The Platonists say that we have access to the essence of justice. Wittgenstein is saying that insofar as we can speak of access in such a case, it is never given as something that can be put into words. In the midst of law-in the intelligible language of law and laws-the 'there is' of justice makes itself manifest. And if you were to say 'our eyes are opened to justice' in this context you would have to say equally that we are utterly in the dark. I think this is a very good comparison for thinking about the Derridean thought of the origin of the force of law. It is the nonpresence of the illuminating but unilluminated 'there is' of justice that is opened to us in the midst of law. And hence it is 'just that there be law'.

In 'Force of Law' Derrida asserts that what he has called 'the mystical' is related to what he calls the aporetic character of any experience of the 'there is' of justice (1992, p. 15). This relationship between present laws and the unpresentable 'there is' of justice that is invoked whenever there is 'a call for justice' is closely related to what Derrida calls the experience of an aporia in the situation of legal reasoning. An aporetic situation in general arises when you are confronted with a puzzle or contradiction which you cannot find a way out of or beyond. A 'poros' is a path in Greek, 'a-poros' is where you have no path. The experience of aporia that Derrida will explore as internal to the call for justice makes of the latter an 'experience that we are not able to experience' (1992, p. 16): the 'there is justice' is never given in the form of being present or as something present. This is a crucial distancing from classical 'theoreticist' Platonism for which there is a kind of (mental) seeing (theoria) involved here: having our (mind's-)eyes opened to the ideal logos of justice. Derrida does not completely deny this because he wants to say that the experience of the inadequation of laws presumes this openness to justice. However, Derrida wants to say that this is not an openness to some ideal content that can be put into words, not an openness to anything presentable in the form of something present, not even in the form of an anticipated future present of ideal adequacy or an idea in the Kantian sense. Indeed, as we shall see, having your eyes opened to justice is in a certain way a matter of having your eyes...closed. 
To clarify the aporetic character of legal reasoning, Derrida develops a (non pure) distinction between justice and law. Laws have a structure of generality. They apply to anyone and they apply to all equally at all times. And when we get involved with legal reasoning, laws and general standards of evidence are articulated in a kind of calculation of a verdict. The justification for a certain verdict, what legal people call 'argument', legal argument, can thus be represented as a form of rational calculation. By contrast, according to Derrida, justice concerns a relation that always turns out to be in some way singular: each case is other. The occasion (the case, the defendant) is each time new, and this 'each one the only one' brings in a dimension that Derrida calls incalculable. But now the tension between (general) law and (singular) justice would seem to make every effort at doing justice through legal reasoning strictly impossible. If law always implies an element of universality and if justice is always related to the singularity of the case, the unique case to which we must do justice, then law in its generality, would seem to make the rendering of justice through legal reasoning impossible. For Derrida, however, this tension is not a fault in the law that we should strive to remove: it is irreducible, unsurpassable. It is something one can only endure: it characterises the situation for the one who is involved in legal reasoning that they are obliged (by justice) to calculate with the incalculable. It is in law, in the generality of the law, a generality that applies universally, that this owing of justice, this singular owing of justice to the other, is most justly achieved.

Now, that would seem to provide a really easy conventionalist route out of any aporia. Within the situation of existing legal norms and customs all you have to do-all you can do, the best you can possibly do-is act in conformity with what the law requires. So is that it then? Is an aporetic condition avoided because it is just to calculate with the incalculable. No.

Why so? Consider, first, conformity to the law, doing what the law demands of one, and going on with it in the same way as before. Generally speaking, no judgment or decision will be regarded as just if the judge does not refer to any law at all. If the judge just improvises, leaves aside all rules, all principles, all precedent, we would not say this is a process of justice, of the just decision. Justice, Derrida puts it again, requires us to calculate: it requires legal reasoning.

On the other hand, if the judge simply applies a rule and does so in conformity with all given rules and conventions that would authorise calculation, if the judge makes himself or herself, as Derrida puts it, a kind of calculating machine, a machine that simply outputs a programmable application of a rule, the unfolding of a calculable process, then while that decision may indeed be legal it would not guarantee, says Derrida, that it will be just.

In fact, there are two limits about the just exercise of the law: no exercise of the law can be just unless it is neither pure improvisation nor pure conformity. Here, and within the structure of legal reasoning and judgement, we have an aporia. To be just, the decision cannot be made purely mechanically. It must be made by someone who we would call free and responsible, not mechanical, not simply making himself or herself into a calculating machine. The undertaking of legal reasoning to a decision must be made by someone who is acting in a knowledgeable way in the midst of the law, not operating in a vacuum or in pure improvisation (pure 
irresponsibility). But this responsibility is no longer responsible if it is pure conformity (pure irresponsibility). The just decision demands both that one acts in the midst of law and in a certain freedom from it, in what Derrida calls a suspension of the law as calculable programme. This is the aporia in the relation of law and justice, and it arises because the just decision must take place both in the midst of the law (reason) and in suspension of the law (freedom). Each time and without any assurance that it is just one must (mechanically) reason but one must also (freely) decide.

The just decision must be neither pure play or improvisation nor pure mechanical calculation. It is, Derrida suggest, recalling Kierkegaard, a moment of madness, a madness within legal reasoning, which is good.

The word 'madness' may be thought inappropriate here because when we talk about madness we are talking about somebody who is neither reasonable, nor free and responsible. But here, it is precisely a matter of madness as rational responsibility; beyond the programmable and the calculable it signifies a sort of ultra-responsibility on the part of the judge (the deciding authority). So, for Derrida, this notion of the just decision is radically tied to a discourse on responsibility in the midst of law: a discourse of responsible judgment. It is imperative to argue, to reason, to give reasons to provide a justification. But reasoning and justification comes to an end somewhere - and then one must decide. And at that moment, in the moment of madness, at the moment of greatest responsibility, one is precisely not the autonomous, sovereign will of a rational speaking subject, the cogito or the ich denke: in the beginning was the deed, the response, a certain leap in the dark.

So we have the violent structure of the founding deed. But Derrida clearly wants to distinguish this from the assumption behind the simple summary that construes law as merely in the service of arbitrary power, a bare assertion of hegemonic will, where 'might makes right'. On such a view, the law will be distinguishable from justice until the political question is dealt with and the interests of justice as such reigns supreme. For Derrida, however, a certain violence, a certain limit of justification, is irreducible, unavoidable - and just. It is just that there is this violence.

The conventionalist cannot get beyond conformity to the law. The classical Platonist, on the other hand, refuses to accept that laws are mere conventions, and insists that the well-adjusted mind has its eyes opened to 'justice as such', and hence that the just decision is oriented towards the truth. Derrida shares the Platonist's objections to conventionalism, and he retains the Platonist's sense of the importance of reasoning and of 'getting all the facts'. However, he shares the conventionalist's objections to the Platonist idea that there is a truth of justice, completely independently of anything that we do. Derrida's is a non-conventionalist anticognitivism about justice. The attempt to ground decisions on a purely constative operation is always resisted by Derrida. On his account, one can never wholly remove the performativity that belongs both to the founding acts and to decisions they make possible. Wherever there is law there is a performative dimension irreducible to truth, a performativity that speaks of the unpresentable 'there is' of justice.

Derrida thinks that even the most revolutionary judgment, the one which would set a completely new precedent or found a new law, still as he puts it, plays on 
something from an 'anterior law' (1992, p. 41) that it will extend or radicalise. So the idea of a pure historical break (as if revolution was a complete separation from the past) is always a kind of illusion for Derrida: there is always some 'anterior law' in some form. The fresh judgment, says Derrida, can very well, must very well and in some way conform to preexisting law. On the other hand, it cannot merely do so as if every other, every case, is already anticipated in the horizon of present law leaving nothing to come. And justice is, Derrida thinks, that experience without experience of the 'to come' of justice, beyond any horizon of present legality. It is the truth of the simple summary.

But the simple summary is ultimately misleading. Because of the generality of the law, and the singularity that is always involved with questions of justice, the ideal of the finally just system of law, the idea of a system of law of ideal adequacy that would, as it were, deliver justice beyond further reform, and which, crucially, could anticipate every other, is a theoreticist illusion. Indeed, a sort of 'transcendental illusion': a shadow cast by the moment of madness that speaks without speaking of the 'there is' of justice.

I want to finish with a story, and it is very important that it is a story, a fiction. Because for Derrida any attempt to state (speak) the origin of the force of law will necessarily involve a kind of fictive narrativity. It is not just a fictional story (a work of imagination) but, as it were, the fiction of a narrative. It is a misfiring attempt to say something about the mystical limit, and yet, as Wittgenstein put it, such attempts 'point to something': it is a fictive narrative through which we might give to ourselves a picture of the origin of the force of law. It is a short story by Kafka. In Kafka's novel The Trial the story is related again, and related as a fictive narrative told by a priest to a man who has been arrested for he does not know what. The man wants to find out not only what he has supposedly done wrong but also the source of the authority of the order to place him under arrest. The fictive narrative told by a priest towards the end of the story in The Trial is one of the very few things that Kafka published in his lifetime as a text to which he gave his name. And while it is a moment within The Trial it turns out to describe the structure of The Trial itself, as a kind of mise en abyme. The title of the short story is 'Before the Law' and the first line also begins with the words 'Before the law'. Here it is.

\section{Before the Law}

Before the law sits a gatekeeper. To this gatekeeper comes a man from the country who asks to gain entry into the law. But the gatekeeper says that he cannot grant him entry at the moment. The man thinks about it and then asks if he will be allowed to come in sometime later on. 'It is possible,' says the gatekeeper, 'but not now.' The gate to the law stands open, as always, and the gatekeeper walks to the side, so the man bends over in order to see through the gate into the inside. When the gatekeeper notices that, he laughs and says: 'If 
it tempts you so much, try going inside in spite of my prohibition. But take note. I am powerful. And I am only the lowliest gatekeeper. But from room to room stand gatekeepers, each more powerful than the last. I cannot endure even one glimpse of the third.' The man from the country has not expected such difficulties: the law should always be accessible for everyone, he thinks, but as he now looks more closely at the gatekeeper in his fur coat, at his large pointed nose and his long, thin, black Tartar's beard, he decides that it would be better to wait until he gets permission to go inside. The gatekeeper gives him a stool and allows him to sit down at the side in front of the gate. There he sits for days and years. He makes many attempts to be let in, and he wears the gatekeeper out with his requests. The gatekeeper often interrogates him briefly, questioning him about his homeland and many other things, but they are indifferent questions, the kind great men put, and at the end he always tells him once more that he cannot let him inside yet. The man, who has equipped himself with many things for his journey, spends everything, no matter how valuable, to win over the gatekeeper. The latter takes it all but, as he does so, says, 'I am taking this only so that you do not think you have failed to do anything.' During the many years the man observes the gatekeeper almost continuously. He forgets the other gatekeepers, and this first one seems to him the only obstacle for entry into the law. He curses the unlucky circumstance, in the first years thoughtlessly and out loud; later, as he grows old, he only mumbles to himself. He becomes childish and, since in the long years studying the gatekeeper he has also come to know the fleas in his fur collar, he even asks the fleas to help him persuade the gatekeeper. Finally his eyesight grows weak, and he does not know whether things are really darker around him or whether his eyes are merely deceiving him. But he recognizes now in the darkness an illumination which breaks inextinguishably out of the gateway to the law. Now he no longer has much time to live. Before his death he gathers up in his head all his experiences of the entire time into one question which he has not yet put to the gatekeeper. He waves to him, since he can no longer lift up his stiffening body. The gatekeeper has to bend way down to him, for the difference between them has changed considerably to the disadvantage of the man. 'What do you want to know now?' asks the gatekeeper. 'You are insatiable.' 'Everyone strives after the law,' says the man, 'so how is it that in these many years no one except me has requested entry?' The gatekeeper sees that the man is already dying and, in order to reach his diminishing sense of hearing, he shouts at him, 'Here no one else can gain entry, since this entrance was assigned only to you. I'm going now to close it.'

I think the law in question here is law with a capital L, and as such it maintains the non-purity of any putative distinction between law and justice. The simple summary calls for that distinction. While attempting consistently to distinguish law and justice in the way I have outlined, Derrida, from the start, refuses that simple construal. Interestingly and obviously in a lot of our language and heritage there will be some kind of distinction between 'the law' and 'laws'. And in the religious tradition, 'the Law' will have a position akin to that of justice as I have been talking 
about: it will be the disclosure to humanity of what is right and just. I think that capital L Law is what interests Kafka in this story. And if you think about the religious law in the Jewish tradition which he comes from we should recall that it is a tradition in which the Law is both the revealed word and the object of interpretation for which interpretation never comes to an end.

However, the structural point that is perhaps most interesting here is the narrated fiction of the singularity of the Law as it is described at the end by the doorkeeper, and the generality of the Law that the man from the country assumes must belong to it, something applicable not just to him but to everyone and at all times. What is revealed to him at the end is that the gate to the Law was only made for him, that the Law is Law only insofar as it maintains a relation to the singular, the unique, the unreplaceable, the unsubstitutable. It will be before the law that the 'there is' of justice breaks through inextinguishably_-but never in the form of something present or presentable: always, in every present, 'not yet' in view.

It is just that there is legal reasoning. Legal justification is just. But justification comes to an end somewhere: there is a limit to the giving of reasons. Reasons give out. But where justification comes to an end there is not the certain perception of truthbut: acting without reasons, without a secure covenant in reason for its correctness. The judge must act, decide, respond, invent the law at the very moment of remaining most faithful to it. I had said that I was intrigued that my colleague had interpreted Derrida's explicit Wittgensteinian reference as a reference to the early Wittgenstein. But we should note that the idea that justification 'comes to an end somewhere' - and the idea that when reasons give out we 'act, without reasons' are quotations from the later Wittgenstein (1958, §484, §211). And I am not convinced that Wittgenstein's thought on this topic changes much at all. It is not as if, for example, the later Wittgenstein replaces a mystical limit with a practical one. It is not mysticism or pragmatism, ever. Rather, he speaks against the explanatory voices of both historicist conventionalism and intellectualist Platonism, and does so throughout with the phenomenological voice of description of what we do. Derrida's philosophico-deconstructive questions in the philosophy of law, and his double-handed engagement with conventionalism and Platonism belongs with this tradition, close especially to the Husserlian critique of intellectualism and historicism in his work on the origin of geometry (Husserl 1970, pp. 353-378). Derrida's text does not offer a history of conventions, nor an analysis of a pure ideality. It sides with the conventionalist in thinking that the only thing we can milk out of different legal institutions are customs and conventions, and it sides with the Platonist in thinking law has a history. But it does not conceive that history either relativistically or teleologically: there is progress, there are advances, through juridico-political struggles against the experienced inadequacy of prevailing laws, and these advances are real and necessary. But they do not have a telos in a condition of ideal adequacy. Rather, they relate to concrete tasks brought to light by the opening onto the 'there is' and 'not yet' of justice that takes place in the midst of law.

Open Access This article is distributed under the terms of the Creative Commons Attribution 4.0 International License (http://creativecommons.org/licenses/by/4.0/), which permits unrestricted use, distribution, and reproduction in any medium, provided you give appropriate credit to the original author(s) and the source, provide a link to the Creative Commons license, and indicate if changes were made. 


\section{References}

Austin, J.L. 1975. How to do things with words. Massachusetts: Harvard University Press.

Derrida, Jacques. 1988. The ear of the other. Lincoln: University of Nebraska Press.

Derrida, Jacques. 1992. Force of law: The 'mystical foundations of authority'. In Deconstruction and the possibility of justice, ed. Drucilla Cornell, Michel Rosenfeld, and David Carlson. London: Routledge.

Derrida, Jacques. 1998. Of grammatology. Baltimore: John Hopkins University Press.

Glendinning, Simon. 2011. Sentencing Derrida. Modern Law Review 74(2): 306-321.

Goodrich, Peter, Florian Hoffmann, Michel Rosenfeld, and Cornelia Vismann (eds.). 2008. Derrida and legal philosophy. London: Palgrave Macmillan.

Husserl, Edmund. 1970. The origin of geometry. In The crisis of European sciences and transcendental phenomenology. Evanston: Northwestern University Press.

Mill, John Stuart. 1978. On liberty. Indianapolis: Hackett.

Murray, Michael (ed.). 1978. Heidegger and modern philosophy. New Haven: Yale University Press.

Wittgenstein, Ludwig. 1958. Philosophical investigations. Oxford: Blackwell.

Wittgenstein, Ludwig. 1961. Tractatus logic-philosophicus. London: Routledge.

Wittgenstein, Ludwig. 1993. Lecture on ethics. In Philosophical occasions, ed. Klagge and Nordmann. Indianapolis: Hackett. 